University of Nebraska - Lincoln

DigitalCommons@University of Nebraska - Lincoln

$9-1973$

\title{
Characteristics of Deoxyribonucleic Acid Polymerase Isolated from Spores of Rhizopus stolonifer
}

\author{
Cheng-Shung Gong \\ University of Nebraska-Lincoln \\ Larry Dunkle \\ University of Nebraska-Lincoln \\ James L. Van Etten \\ University of Nebraska-Lincoln, jvanetten1@unl.edu
}

Follow this and additional works at: https://digitalcommons.unl.edu/plantpathpapers

Part of the Plant Pathology Commons

Gong, Cheng-Shung; Dunkle, Larry; and Van Etten, James L., "Characteristics of Deoxyribonucleic Acid Polymerase Isolated from Spores of Rhizopus stolonifer" (1973). Papers in Plant Pathology. 145.

https://digitalcommons.unl.edu/plantpathpapers/145

This Article is brought to you for free and open access by the Plant Pathology Department at DigitalCommons@University of Nebraska - Lincoln. It has been accepted for inclusion in Papers in Plant Pathology by an authorized administrator of DigitalCommons@University of Nebraska - Lincoln. 


\title{
Characteristics of Deoxyribonucleic Acid Polymerase Isolated from Spores of Rhizopus stolonifer ${ }^{1}$
}

\author{
CHENG-SHUNG GONG, LARRY D. DUNKLE, AND JAMES L. VAN ETTEN \\ Department of Plant Pathology, University of Nebraska, Lincoln, Nebraska 68503
}

Received for publication 23 April 1973

\begin{abstract}
Deoxyribonucleic acid (DNA)-dependent DNA polymerase was purified several hundredfold from germinated and ungerminated spores of the fungus Rhizopus stolonifer. The partially purified enzymes from both spore stages exhibited identical characteristics; incorporation of $\left[{ }^{3} \mathrm{H}\right]$ deoxythymidine monophosphate into DNA required $\mathrm{Mg}^{2+}$, DNA, a reducing agent, and the simultaneous presence of deoxyguanosine triphosphate, deoxycytidine triphosphate, and deoxyadenosine triphosphate. Heat-denatured and activated DNAs were better templates than were native DNAs. The buoyant density of the radioactive product of the reaction was similar to that of the template DNA. The enzyme is probably composed of a single polypeptide chain with an $S$ value of 5.12 and an estimated molecular weight of 70,000 to 75,000 . During the early stages of purification, the enzyme fraction from ungerminated spores required exogenous DNA for maximum activity, whereas the corresponding enzyme fraction from germinated spores did not require added DNA. Apparently DNA polymerase from germinated spores was more tightly bound to endogenous DNA than was the enzyme from ungerminated spores.
\end{abstract}

The initiation of fungal spore germination ultimately results in a rapid increase in the rate of macromolecular biosynthesis. During the germination of spores of Rhizopus stolonifer and Botryodiplodia theobromae, deoxyribonucleic acid (DNA) synthesis is initiated after the onset of protein and ribonucleic acid (RNA) syntheses $(4,7,8)$. Analyses of DNA demonstrated that the base composition and other properties were unaltered during the germination process in these two fungi (7).

Although DNA-dependent DNA polymerase (deoxyribonucleoside triphosphate: DNA deoxyribonucleotidyl transferase, EC 2.7.7.7) has been studied extensively in several prokaryotic organisms (see review 12), many eukaryotic organisms $(5,6,9,13,18-20,22,23,25,26)$, and mitochondria $(10,11,17,27)$, we are not aware of any reports that describe the characteristics of this enzyme from mycelial fungi, especially as they relate to the biosynthetic activities associated with fungal spore germination. This report presents data on the purification and properties of DNA polymerase isolated from

\footnotetext{
' Published as paper no. 3553, Journal Series, Nebraska Agricultural Experiment Station. Research reported was conducted under project no. 21-17.
}

ungerminated and germinated spores of $R$. stolonifer.

\section{MATERIALS AND METHODS}

Materials. $\left[{ }^{3} \mathrm{H}\right]$ deoxythymidine triphosphate (dTTP) $(12.4 \mathrm{Ci} / \mathrm{mmol})$ and $\left[{ }^{3} \mathrm{H}\right.$ juridine triphosphate $(22 \mathrm{Ci} / \mathrm{mmol})$ were purchased from New England Nuclear Corp. Actinomycin D and ethidium bromide were purchased from Merck and Co. and Calbiochem, respectively. DNA from cowpea (Vigna unguiculata) was obtained from J. S. Semancik, and tobacco mosaic virus and brome mosaic virus RNAs were obtained from A. O. Jackson. Double-stranded RNA from the bacteriophage $\phi 6$ and DNA from $R$. stolonifer were prepared in our laboratory (7). The remainder of the inhibitors, DNAs, and marker proteins were purchased from Sigma Chemical Co., except for the synthetic nucleic acids, poly $[\mathrm{d}(\mathrm{A}-\mathrm{T})]$ and poly dT - poly rA, which were purchased from Miles Laboratories, Inc. The techniques for growth, harvesting, and germination of $R$. stolonifer sporangiospores were identical to those previously described (24).

Purification of DNA polymerase. Cell-free extracts from ungerminated and 6 -h germinated spores were prepared as described previously (8). DNA polymerase was partially purified from the $105,000 \times$ $g$ supernatant fraction by 25 to $65 \%\left(\mathrm{NH}_{4}\right)_{2} \mathrm{SO}_{4}$ fractionation. The precipitate was dissolved in buffer A $(0.05 \mathrm{M}$ potassium phosphate, $0.01 \mathrm{M} 2$-mercapto- 
ethanol, $\mathrm{pH}$ 7.4) and dialyzed overnight against this buffer.

The enzyme fraction was applied to a phosphocellulose column ( 2 by $20 \mathrm{~cm}$ ), equilibrated with buffer $A$, and washed with additional buffer A. DNA polymerase activity was eluted from the column by increasing the potassium phosphate concentration linearly from $0.05 \mathrm{M}$ to $0.06 \mathrm{M}$. The fractions exhibiting DNA polymerase activity were pooled and precipitated with $70 \%\left(\mathrm{NH}_{4} \mathrm{SO}_{4}\right.$. The precipitate was dissolved in buffer $\mathrm{B}$ [0.05 $\mathrm{M}$ tris(hydroxymethyl)aminomethane (Tris), pH 8.0;0.001 $\mathrm{M} \mathrm{MgCl}_{2} ; 0.01 \mathrm{M}$ 2-mercaptoethanol; $10^{-4} \mathrm{M}$ ethylenediaminetetraacetic acid; $\left.0.05 \mathrm{M}\left(\mathrm{NH}_{4}\right)_{2} \mathrm{SO}_{4}\right]$ and dialyzed against this buffer. The dialysate was applied to a diethylaminoethyl (DEAE)-Sephadex (A-50-120) column $(0.9$ by $10 \mathrm{~cm})$ that had been equilibrated with buffer $B$. The enzyme was eluted with a linear gradient from $0.05 \mathrm{M}$ to $0.6 \mathrm{M}$ $\left(\mathrm{NH}_{4}\right)_{2} \mathrm{SO}_{4}$. The fractions that exhibited DNA polymerase activity were pooled and used for the enzyme assays unless otherwise indicated.

Enzyme assays. DNA polymerase activity was determined in an assay mixture containing in a final volume of $1 \mathrm{ml}$ : Tris ( $\mathrm{pH} 8.4)(50 \mu \mathrm{mol}), \mathrm{MgCl}_{2}(7$ $\mu \mathrm{mol})$, dithiothreitol $(10 \mu \mathrm{mol}), \mathrm{KCl}(40 \mu \mathrm{mol})$, deoxyadenosine triphosphate (dATP), deoxyguanosine triphosphate (dGTP), and deoxycytidine triphosphate (dCTP) $(0.05 \mu \mathrm{mol}$ each), activated calf thymus DNA (50 $\mathrm{\mu g})$, and 'H-labeled deoxythymidine triphosphate ([' $\mathrm{H}] \mathrm{dTTP})(5 \mu \mathrm{Ci})$. The assay tubes were incubated at $30 \mathrm{C} ; 0.05-\mathrm{ml}$ samples were removed at various times and applied to filter paper disks, and the paper disks were processed as described by Bollum (2). To monitor a column or gradient, the assays were conducted by adding $0.05-\mathrm{ml}$ samples from column effluents or gradient fractions to $0.07 \mathrm{ml}$ of the reaction mixture and incubating at 30 $\mathrm{C}$ for 30 or $60 \mathrm{~min}$. The reaction was stopped by putting the tubes on ice, applying $0.1-\mathrm{ml}$ samples to filter paper disks, and processing the disks as described above. The specific activity was expressed as picomoles of deoxythymidine monophosphate (dTMP) incorporated per milligram of protein per hour.

RNA polymerase (EC 2.7.7.6) activity was determined by methods previously described (8). The enzyme preparation was tested for deoxyribonuclease (DNase) (EC 3.1.4.5) activity by incubating it with $R$. stolonifer DNA at $36 \mathrm{C}$ for $30 \mathrm{~min}$ in the presence of $0.01 \mathrm{M} \mathrm{MgCl}$. The DNA was then analyzed on linear-log sucrose density gradients (3). Bovine pancreatic DNase was used as a standard.

Analysis of product on $\mathrm{CsCl}$ gradients. The radioactive product formed with different template DNAs was centrifuged to equilibrium in $\mathrm{CsCl}$ gradients and fractionated as described previously (7). The radioactive product was synthesized in the standard assay mixture with the following modifications: $1 \mathrm{ml}$ of reaction mixture contained $200 \mu \mathrm{g}$ of either native salmon sperm DNA or $R$. stolonifer DNA, $10 \mu \mathrm{Ci}$ of ['H]dTTP, $0.1 \mu \mathrm{mol}$ each of dATP, dGTP, and dCTP, and $0.02 \%$ sodium azide to prevent bacterial growth. Enzyme (50 $\mu$ g) was added to the reaction mixture, and the mixture was incubated at $30 \mathrm{C}$ for 3 h. An excess of unlabeled dTTP was added and the reaction was allowed to proceed for $1 \mathrm{~h}$ longer. The nucleic acids were precipitated with ethanol, dissolved in $0.015 \mathrm{M} \mathrm{NaCl}, 0.0015 \mathrm{M}$ sodium citrate, $\mathrm{pH}$ $7.0(0.1 \times \mathrm{SSC}$ buffer $[0.15 \mathrm{M} \mathrm{NaCl}$ plus $0.015 \mathrm{M}$ sodium citrate ]), and dialyzed overnight against 0.01 $\times \mathrm{SSC}$ before being applied to $\mathrm{CsCl}$ gradients.

Estimations of molecular weight. The molecular weight of DNA polymerase was estimated on a Sephadex G-150 column by using bovine albumin, horse heart cytochrome $c$, and ovalbumin as standards. Polyacrylamide gel electrophoresis was conducted on $10-\mathrm{cm} 6 \%$ acrylamide gels in sodium dodecyl sulfate as described by Maizel (15). The protein bands were observed after staining with Coomassie brilliant blue. The molecular weights of the polypeptides were estimated on these gels by the procedure of Shapiro et al. (21) by using cytochome $c$, ovalbumin, and pepsin as standards. Rate sedimentation analyses were performed on linear-log sucrose density gradients equilibrated with buffer B (3) with ribonuclease (RNase) $A$, ovalbumin, and bovine albumin as standards.

Other procedures. The nucleic acids used as templates were dissolved in $1 \times$ SSC buffer. Denatured nucleic acids were obtained by heating at $100 \mathrm{C}$ for $10 \mathrm{~min}$ and quickly cooling. Activated DNA was prepared as described by Aposhian and Kornberg (1). Protein was determined by the method of Lowry et al. (14) with bovine albumin as a standard.

\section{RESULTS}

Purification and characteristics of the enzyme. The partial purification of DNA polymerase from both spore stages of $R$. stolonifer is shown in Table 1 . The specific activities of the enzyme at the final stage of purification were approximately the same in germinated and ungerminated spores; the final specific activities of individual enzyme preparations ranged from 500 to 1,300 . The fold of purification of the enzyme from ungerminated spores was higher than that from germinated spores as a result of a higher specific activity in the $105,000 \times g$ supernatant fraction from germinated spores. The reason for the difference in specific activities at this stage of purification has not been investigated further. The purified enzyme from both spore stages was quite stable; it retained total activity after freezing and thawing and during dialysis.

DNA polymerase from germinated spores eluted as a single peak from a phosphocellulose' column at a potassium phosphate concentration of $0.27 \mathrm{M}$ (Fig. 1A). Enzyme activity eluted as a single peak from a DEAE-Sephadex column at about $0.18 \mathrm{M}\left(\mathrm{NH}_{4}\right)_{2} \mathrm{SO}_{4}$ (Fig. 1B). After DEAE-Sephadex chromatography, the enzyme fraction was devoid of RNA polymerase and DNase activities. At this stage of purification, DNA polymerase activity from both spore states was completely dependent on exogenous DNA as a template (Table 1). 
TABLE 1. Partial purification of DNA-dependent DNA polymerase from germinated and ungerminated spores of $R$. stolonifer ${ }^{a}$

\begin{tabular}{|c|c|c|c|c|c|c|}
\hline Fraction & $\begin{array}{l}\text { Specific } \\
\text { activity }^{b}\end{array}$ & $\begin{array}{l}\text { Total } \\
\text { protein } \\
(\mathrm{mg})\end{array}$ & $\begin{array}{c}\text { Total } \\
\text { activity }\end{array}$ & $\begin{array}{c}\text { Fold } \\
\text { purification }\end{array}$ & $\begin{array}{l}\text { Recovery } \\
(\%)\end{array}$ & $\begin{array}{c}\text { DNA } \\
\text { dependencyc } \\
(\%)\end{array}$ \\
\hline \multicolumn{7}{|l|}{ Expt 1} \\
\hline $105,000 \times g$ & 0.24 & 6,452 & 1,548 & 1 & 100 & 61 \\
\hline 25 to $65 \%\left(\mathrm{NH}_{4}\right)_{2} \mathrm{SO}_{4}$ & 3.3 & 720 & 2,376 & 13.8 & 153 & 80 \\
\hline $\begin{array}{l}\text { Phosphocellulose chroma- } \\
\text { tography }\end{array}$ & 326 & 2.5 & 815 & 1,358 & 53 & 95 \\
\hline $\begin{array}{l}\text { DEAE-Sephadex chroma- } \\
\text { tography }\end{array}$ & 559 & 0.76 & 425 & 2,329 & 27 & 100 \\
\hline \multicolumn{7}{|l|}{ Expt 2} \\
\hline $105,000 \times g$ & 0.42 & 22,500 & 9,450 & 1 & 100 & 0 \\
\hline 25 to $65 \%\left(\mathrm{NH}_{4}\right)_{2} \mathrm{SO}_{4}$ & 4.2 & 5,880 & 24,696 & 10 & 261 & 68 \\
\hline $\begin{array}{l}\text { Phosphocellulose chroma- } \\
\text { tography }\end{array}$ & 374 & 9.8 & 3,665 & 890 & 39 & 65 \\
\hline $\begin{array}{l}\text { DEAE-Sephadex chroma- } \\
\text { tography }\end{array}$ & 528 & 4.6 & 2,429 & 1,257 & 26 & 100 \\
\hline
\end{tabular}

${ }^{a}$ Experiment 1, ungerminated spores; experiment 2, germinated spores.

${ }^{\circ}$ Measured as picomoles of TMP incorporated per milligram of protein per $30 \mathrm{~min}$.

${ }^{c}$ Difference between $\left[{ }^{3} \mathrm{H}\right] \mathrm{dTMP}$ incorporation in the presence of exogenous DNA and the absence of added DNA, calculated as percentage.

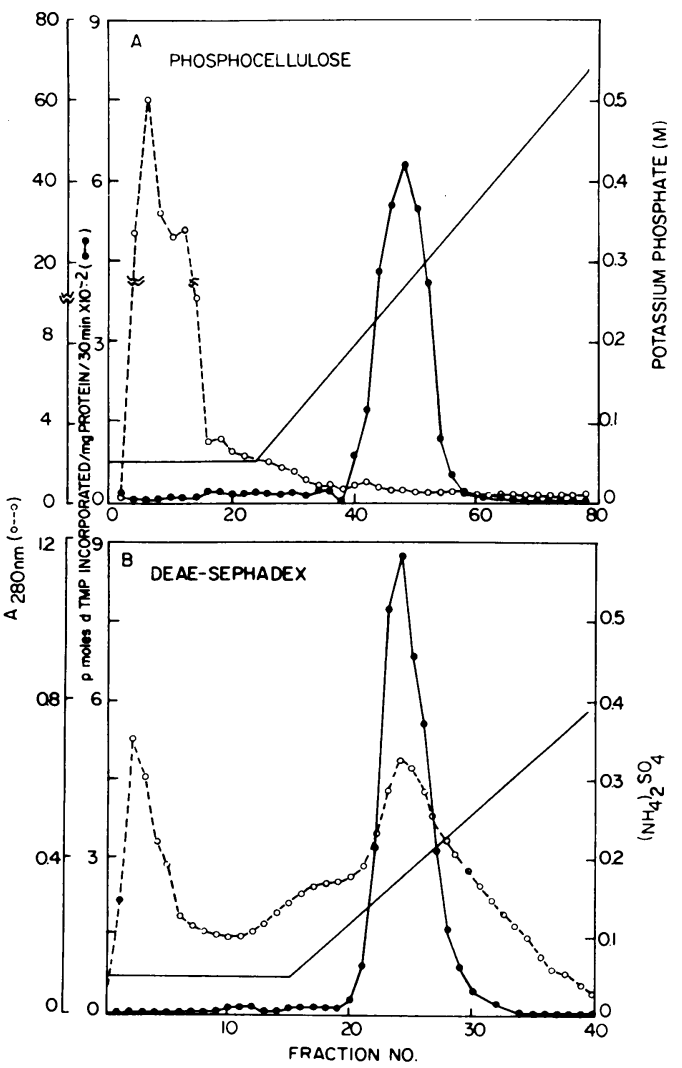

Fig. 1. A, Phosphocellulose column chromatography of DNA polymerase obtained from germinated spores of $R$. stolonifer. About $700 \mathrm{mg}$ of protein were applied to the column; 2-ml fractions were collected
Some characteristics of DNA polymerase from germinated spores of $R$. stolonifer are shown in Table 2 . The reaction was highly dependent on the simultaneous presence of all four deoxyribonucleoside triphosphates. Omission of any one of the three deoxynucleotides reduced $\left[{ }^{3} \mathrm{H}\right] \mathrm{dTMP}$ incorporation more than $90 \%$. Magnesium, with an optimal concentration of 6 to $8 \mathrm{mM}$, and DNA were also essential for $\left[{ }^{3} \mathrm{H}\right] \mathrm{dTMP}$ incorporation. Neither $\mathrm{Mn}^{2+}$ nor $\mathrm{Ca}^{2+}$ could effectively replace $\mathrm{Mg}^{2+}$. When dithiothreitol was omitted from the reaction mixture, incorporation was greatly reduced; 2-mercaptoethanol could replace dithiothreitol. Potassium (40 mM) enhanced [ ${ }^{3} \mathrm{H}$ ]dTMP incorporation by about $50 \%$, but $\mathrm{NH}_{4}{ }^{+}$or $\mathrm{Na}^{+}$at this concentration was ineffective. The enzyme reaction was partially inhibited by low concentrations of actinomycin $\mathrm{D}(0.1 \mu \mathrm{g} / \mathrm{ml})$ and completely inhibited by high concentrations (10 $\mu \mathrm{g} / \mathrm{ml}$ ). The reaction was also inhibited by ethidium bromide, pyrophosphate, and DNase, whereas orthophosphate and RNase had no effect (Table 3).

Native, heat-denatured, and activated DNAs from several sources were tested for template

and assayed for DNA polymerase activity. B, DEAESephadex column chromatography of DNA polymerase after phosphocellulose column chromatography. Protein (9.7 mg) was applied to the column; 1-ml fractions were collected and assayed for DNA polymerase activity. Symbols: 1 , DNA polymerase activity as picomoles of $\left[{ }^{8} \mathrm{H}\right] \mathrm{dTMP}$ incorporated per milligram of protein per $30 \mathrm{~min}$; O, absorbancy at $280 \mathrm{~nm}$; , salt concentration. 
TABLE 2. Characteristics of DNA polymerase from germinated spores of $R$. stolonifer

\begin{tabular}{c|c|c}
\hline Assay mixture & $\begin{array}{c}\text { Specific } \\
\text { activity }^{a}\end{array}$ & $\begin{array}{c}\text { Percentage } \\
\text { of control }\end{array}$ \\
\hline $\begin{array}{c}\text { Complete ....... } \\
\text { Without enzyme }\end{array}$ & 757 & 100 \\
fraction ..... & 0 & 0 \\
Without dGTP, & & \\
dCTP, dATP . & 12 & 1.6 \\
Without dGTP ... & 38 & 5.0 \\
Without dCTP ... & 59 & 7.8 \\
Without dATP ... & 35 & 4.6 \\
Without DNA ... & 0 & 0 \\
Without MgCl . . & 72 & 9.5 \\
Without dithio- & & 2.2 \\
threitol ..... & 17 & 51.1 \\
Without KCl .... & 387 & \\
\hline
\end{tabular}

${ }^{a}$ Measured \&, picomoles of TMP incorporated per milligram of $\mathbf{p}$ stein per hour.

TABLE 3. 'ffect of nucleases, phosphate, and inhibitors on 'he activity of DNA polymerase from germ.nated spores of $R$. stolonifer

\begin{tabular}{l|c|c}
\hline Assay mixtur : & Concn & $\begin{array}{c}\text { Percentage } \\
\text { of control }\end{array}$ \\
\hline Control & $10 \mu \mathrm{g} / \mathrm{ml}$ & $100^{a}$ \\
DNase & $10 \mu \mathrm{g} / \mathrm{ml}$ & 0 \\
RNase & $5 \mathrm{mM}$ & $100^{a}$ \\
Orthophosphate & $5 \mathrm{mM}$ & 90 \\
Pyrophosphate & $0.1 \mu \mathrm{g} / \mathrm{ml}$ & 9.5 \\
Ethidium bromide & $1 \mu \mathrm{g} / \mathrm{ml}$ & 8.5 \\
Ethidium bromide & $10 \mu \mathrm{g} / \mathrm{ml}$ & 0 \\
Ethidium bromide & $0.1 \mu \mathrm{g} / \mathrm{ml}$ & 44.5 \\
Actinomycin D & $1 \mu \mathrm{g} / \mathrm{ml}$ & 9.2 \\
Actinomycin D & $10 \mu \mathrm{g} / \mathrm{ml}$ & 3.1 \\
Actinomycin D & \\
\hline
\end{tabular}

a Equivalent to $1,516 \mathrm{pmol}$ of dTMP incorporated per $\mathrm{mg}$ of protein per $\mathrm{h}$.

activity (Table 4). Denatured DNAs were more effective as templates than were native DNAs, but the highest activity was obtained with activated salmon sperm DNA although the synthetic DNA, poly[d(A-T)], was also very effective. Surprisingly, DNA isolated from $R$. stolonifer was not as effective as a template as were the DNAs from other sources. When the synthetic polynucleotide poly dT - poly rA was tested as a template for the enzyme, no incorporation of $\left[{ }^{3} \mathrm{H}\right] \mathrm{dATP}, \quad\left[{ }^{3} \mathrm{H}\right]$ uridine triphosphate, or $\left[{ }^{14} \mathrm{C}\right] \mathrm{dATP}$ was observed. However, a slight a mount of $\left[{ }^{3} \mathrm{H}\right] \mathrm{dTMP}$ was incorporated, approximately 5 to $10 \%$ of that obtained with poly $[d(A-T)]$. Therefore, the enzyme did have limited ability to synthesize DNA from a DNA:RNA template. Neither the doublestranded RNA from phage $\phi 6$ nor the singlestranded RNAs from tobacco mosaic virus and brome mosaic virus were utilized as a template (Table 4).

Reaction kinetics for the enzyme from both spore stages are shown in Fig. 2. The incorporation of $\left[{ }^{2} \mathrm{H}\right] \mathrm{dTMP}$ into DNA was linear for at least $1 \mathrm{~h}$ and continued to increase for over $2 \mathrm{~h}$. Increasing the enzyme concentration resulted in a proportional increase in $\left.{ }^{2} \mathrm{H}\right] \mathrm{dTMP}$ incorporation (Fig. 3). The optimal temperature for incorporation was $30 \mathrm{C}$; activity was drastically reduced at $37 \mathrm{C}$. DNA polymerase had a $\mathrm{pH}$ optimum at 8.3 in $0.05 \mathrm{M}$ Tris-chloride. Although most of the data shown above were obtained

TABLE 4. Ability of various nucleic acids to serve as a template for DNA polymerase from germinated spores of $R$. stolonifer

\begin{tabular}{l|r|c|r}
\hline \multirow{2}{*}{ Nucleic acid $^{a}$} & \multicolumn{3}{|c}{ Specific activity $^{\circ}$} \\
\cline { 2 - 4 } & Native & Denatured & Activated \\
\hline Control (no DNA) & 0 & & \\
Calf thymus DNA & 127 & 554 & 890 \\
Salmon sperm DNA & 820 & 923 & 1,260 \\
Cowpea DNA & 105 & 238 & \\
Rhizopus stolonifer & 82 & 174 & \\
DNA & & & \\
Escherichia coli DNA & 241 & 270 & \\
Poly[d(A-T)] & 861 & & \\
Phage 06 RNA & 7 & & \\
Tobacco mosaic virus & 1 & & \\
RNA & & & \\
Brome mosaic virus & 0 & & \\
RNA & & & \\
\hline
\end{tabular}

${ }^{a}$ Each assay tube contained $50 \mu \mathrm{g}$ of nucleic acid per $\mathrm{ml}$ except for poly $[\mathrm{d}(\mathrm{A}-\mathrm{T})]$, which contained 30 $\mu \mathrm{g}$.

Measured as picomoles of TMP incorporated per milligram of protein per hour.

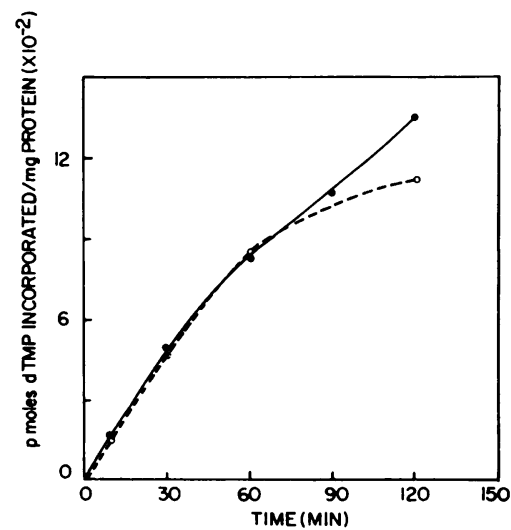

Fig. 2. Time course of incorporation of $\left[{ }^{3} \mathrm{H}\right] d T M P$ into DNA by DNA polymerase from germinated (O) and ungerminated (O) spores of $R$. stolonifer. The amount of enzyme protein was 18 and $14 \mathrm{\mu g}$ for germinated and ungerminated spores, respectively. 


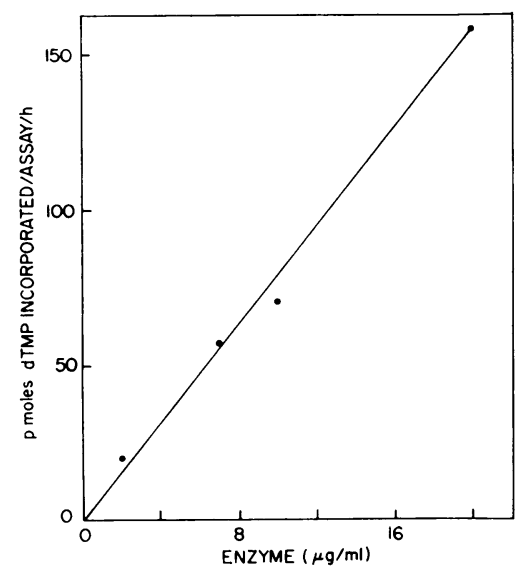

Fig. 3. Relationship of $\left[{ }^{3} \mathrm{H}\right] d T M P$ incorporation with increasing concentrations of protein.

with an enzyme fraction isolated from germinated spores, the same results were obtained with an enzyme fraction from ungerminated spores.

Analysis of product. The radioactive products formed with DNA polymerase was incubated with native salmon sperm DNA $(\rho=$ $1.701)$ or native $R$. stolonifer DNA $(\rho=1.696)$ were analyzed on $\mathrm{CsCl}$ gradients. The results (Fig. 4) indicated that the majority of the radioactivity coincided with the absorbancy at $260 \mathrm{~nm}$ of the template DNA used in the initial assay; therefore, the buoyant density of the reaction product was nearly identical to the template DNA used. Incubation of the acidinsoluble radioactive product with DNase at 37 C for 30 min solubilized more than $90 \%$ of the product. In contrast, RNase had no effect on the product.

Physical properties of the enzyme. Rate sedimentation of DNA polymerase from both spore states with marker proteins in linear-log sucrose density gradients indicated that the enzyme had an $S$ value of 5.12 (Fig. 5A). The molecular weight of the enzyme was estimated to be about 74,000 by Sephadex G-150 column chromatography (Fig. 5B).

After DEAE-Sephadex column chromatography, the enzyme fractions were pooled, dialyzed, and applied to a second phosphocellulose column; the peak fractions, which contained the highest enzyme activity, were individually electrophoresed on sodium dodecyl sulfate-polyacrylamide gels. The polymerase preparation from germinated spores exhibited a major component plus a few minor bands (see insert in Fig. 5C). The amount of the major component corresponded with the polymerase activity profile obtained from the phosphocel- lulose column. With the same procedure with enzyme prepared from ungerminated spores, the absorption profile of the gel was similar to that of the enzyme from germinated spores. The molecular weight of the major polypeptide was estimated to be 72,000 (Fig. $5 \mathrm{C}$ ).

Binding of DNA polymerase to DNA during spore germination. The dependency of DNA polymerase from the two spore stages on exogenous DNA is shown in Table 1. The activity of the $105,000 \times g$ supernatant fraction from the ungerminated spore was highly dependent on exogenous DNA, whereas the corresponding germinated spore enzyme was not stimulated by exogenous template DNA. These results suggest that the ungerminated spore DNA polymerase either is not tightly bound to DNA or exists free of DNA; in contrast, the germinated spore enzyme may be more tightly bound to DNA. Further evidence that the germinated spore enzyme is bound to DNA is presented in Fig. 6 . The $105,000 \times g$ supernatant fraction from germinated spores was applied directly to linear-log glycerol density gra-

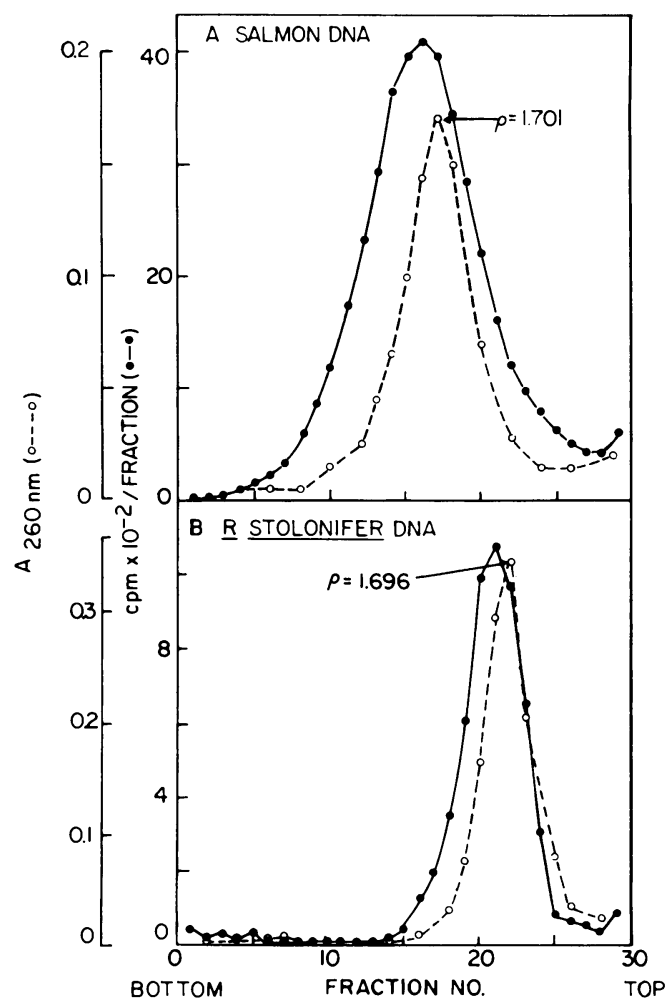

Fig. 4. CsCl equilibrium density gradient centrifugation of $\left[{ }^{3} H\right] D N A$ synthesized in the presence of $(A)$ native salmon sperm DNA or $(B)$ native $R$. stolonifer DNA. Symbols: O, absorbancy at $260 \mathrm{~nm}$;, radioactivity. 

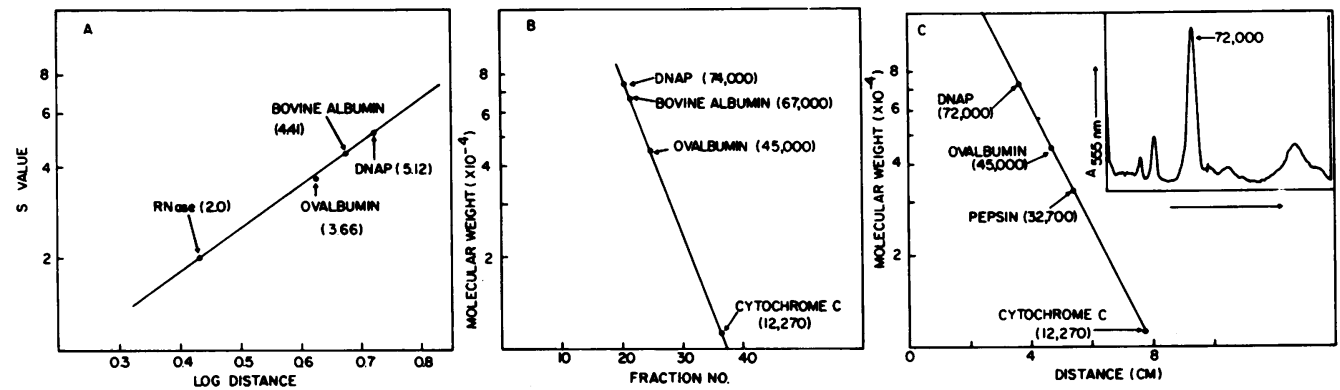

Fig. 5. A, Plot of the $S$ values of marker proteins versus the log of the distance sedimented as determined on linear-log sucrose density gradients. The $S$ value of the DNA polymerase from germinated spores of $R$. stolonifer is indicated. B, Estimation of the molecular weight of DNA polymerase from germinated spores of $R$. stolonifer as determined by Sephadex G-150 column chromatography. C, Estimation of the molecular weight of the major protein band present in the purified enzyme fraction from germinated spores of $R$. stolonifer. The molecular weight was estimated with marker proteins after electrophoresis on $6 \%$ polyacrylamide gels. The insert contains a scan of the purified enzyme fraction after electrophoresis and staining with Coomassie brilliant blue.

dients equilibrated with buffer $B$; the individual fractions were assayed for DNA polymerase activity in the presence and absence of exogenous template DNA. The majority of the DNA polymerase activity sedimented rapidly in the gradient, and the addition of exogenous DNA had little effect on activity (Fig. 6A). However, when the $105,000 \times g$ supernatant fraction from germinated spores was treated with DNase before layering onto the gradient, the enzyme activity sedimented more slowly in the gradient and was completely dependent on exogenous DNA for activity (Fig. 6B).

\section{DISCUSSION}

During spore germination in $R$. stolonifer, labeled precursors are incorporated into DNA between 1 and $2 \mathrm{~h}$ after the initiation of germination, and the incorporation rate increases rapidly thereafter (7). The increases in synthetic rate and in cellular content of DNA are accompanied by an increase in total DNA polymerase activity (unpublished data). The lack of DNA synthesis early in the germination process is not a result of the absence of DNA polymerase, since an active enzyme was isolated from ungerminated spores. To assure that harvesting the spores in water did not activate or initiate synthesis of DNA polymerase, the enzyme was also isolated from dry-harvested spores (16). The characteristics and activity of this enzyme were identical with those of the enzyme from water-harvested spores.

DNA polymerase from $R$. stolonifer has properties and requirements that are similar to those of DNA polymerase purified from other eukaryotic organisms $(5,18,19,22,25)$. In general, the enzymes from these organisms have an alkaline $\mathrm{pH}$ optimum, require $\mathbf{M g}^{2+}$, are less

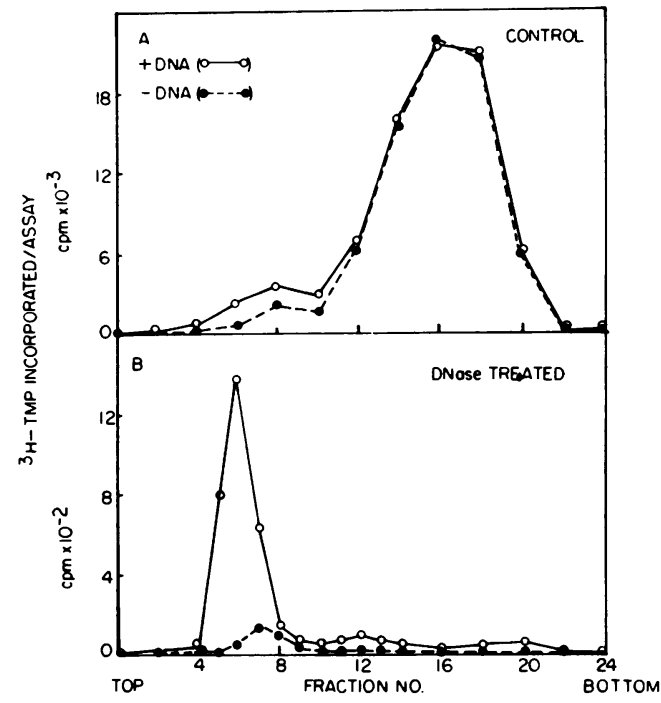

Fig. 6. Rate sedimentation on linear-log glycerol density gradients of the $105,000 \times \mathrm{g}$ supernatant fraction from germinated spores of $R$. stolonifer. Symbols: $0, D N A$ polymerase activity in the absence of added template DNA; O, enzyme activity in the presence of added template. A, Activity of the untreated crude supernatant fraction. $B$, Activity after treatment of the crude supernatant fraction with DNase before layering on the column.

active in the presence of other divalent cations, and exhibit a preference for activated (DNase 1-treated) or heat-denatured DNAs as templates. The molecular weights of DNA polymerase from eukaryotic organisms vary considerably. For example, the molecular weight of DNA polymerase from rabbit bone marrow was estimated to be 40,000 to 50,000 (5), whereas the enzyme from sea urchin embryo nuclei has a molecular weight of approximately $150,000(25)$. 
The molecular weight of DNA polymerase from $R$. stolonifer is approximately 70,000 to 75,000 .

Several lines of evidence suggest to us that the enzyme described in this report is of nuclear origin. Attempts to isolate DNA polymerase from mitochondria of $R$. stolonifer were unsuccessful. Furthermore, the molecular weight of yeast mitochondrial DNA polymerase is much greater than that of the $R$. stolonifer enzyme (27). Experiments to establish that the enzyme from germinated spores was bound to nuclear DNA and not to mitochondrial DNA could not be conducted because in this organism both DNA species have the same buoyant density in $\mathrm{CsCl}$ (7).

The results of this study corroborate the conclusions from our previous studies and indicate that fungal spores contain the essential biosynthetic enzymes and other components required for growth. Except for changes in RNA polymerases (8) and minor changes in some isoaccepting species of transfer RNA (16) during germination of $R$. stolonifer spores, the properties of these constituents do not change significantly during the course of germination.

\section{ACKNOWLEDGMENTS}

We are indebted to $M$. K. Brakke for his advice and to R. K. Koski and Merrilee Rutledge for their technical assistance. This investigation was supported by Public Health Service grant AI 108057 from the National Institute of Allergy and Infectious Diseases.

\section{LITERATURE CITED}

1. Aposhian, H. V., and A. Kornberg. 1962. Enzymatic synthesis of deoxyribonucleic acid. IX. The polymerase formed after $\mathrm{T}_{\mathbf{2}}$ bacteriophage infection of Escherichia coli: a new enzyme. J. Biol. Chem. 237:519-525.

2. Bollum, F. J. 1967. Filter paper disk techniques for assaying radioactive macromolecules, p. 169-173. In L. Grossman and K. Moldave (ed.), Methods in enzymology, vol. 12B. Academic Press Inc., New York.

3. Brakke, M. K., and N. Van Pelt. 1970. Linear-log sucrose gradients for estimating sedimentation coefficients of plant viruses and nucleic acids. Anal. Biochem. 38:56-64.

4. Brambl, R. M., and J. L. Van Etten. 1970. Protein synthesis during fungal spore germination. V. Evidence that the ungerminated conidiospores of Botryodiplodia theobromae contain messenger ribonucleic acid. Arch. Biochem. Biophys. 137:442-452.

5. Chang, L. M. S., and F. J. Bollum. 1972. Low molecular weight deoxyribonucleic acid polymerase from rabbit bone marrow. Biochemistry 11:1264-1272.

6. Crerar, M., and R. E. Pearlman. 1971. DNA polymerase activity from Tetrahymena pyriformis. FEBS Lett. 18:231-237.

7. Dunkle, L. D., and J. L. Van Etten. 1972. Characteristics and synthesis of deoxyribonucleic acid during fungal spore germination, p. 283-289. In H. O. Halvorson, R. Hanson, and L. L. Campbell (ed.), Spores V. American Scoiety for Microbiology, Washington, D.C.

8. Gong, C.-S., and J. L. Van Etten. 1972. Changes in soluble ribonucleic acid polymerase associated with the germination of Rhizopus stolonifer spores. Biochim Biophys. Acta 272:44-52.

9. Howk, R., and T. Y. Wang. 1969. DNA polymerase from rat liver chromosomal proteins. I. Partial purification and general characteristics. Arch. Biochem. Biophys. 133:238-246.

10. Iwashima, A., and M. Rabinowitz. 1969. Partial purification of mitochondria and supernatant DNA polymerase from Saccharomyces cerevisiae. Biochim. Biophys. Acta 178:283-293.

11. Kalf, G. F., and J. J. Ch'ih. 1968. Purification and properties of deoxyribonucleic acid polymerase from rat liver mitochondria. J. Biol. Chem. 243:4904-4916.

12. Klein, A., and F. Bonhoeffer. 1972. DNA replication. Annu. Rev. Biochem. 41:301-332.

13. Loeb, L. A. 1969. Purification and properties of deoxyribonucleic acid polymerase from nuclei of sea urchin embryos. J. Biol. Chem. 244:1672-1681.

14. Lowry, O. H., N. J. Rosebrough, A. L. Farr, and R. J. Randall. 1951. Protein measurement with the Folin phenol reagent. J. Biol. Chem. 133:265-275.

15. Maizel, J. V. 1969. Acrylamide gel electrophoresis of protein and nucleic acid, p. 334-362. In K. Habel and N. P. Salzman, (ed.), Fundamental techniques in virology. Academic Press Inc., New York.

16. Merlo, D. J., H. Roker, and J. L. Van Etten. 1972. Protein synthesis during fungal spore germination. VI. Analysis of transfer ribonucleic acid from germinated and ungerminated spores of Rhizopus stolonifer. Can. J. Microbiol. 18:949-956.

17. Meyer, R. R., and M. V. Simpson. 1968. DNA biosynthesis in mitochondria: partial purification of a distinct DNA polymerase from isolated rat liver mitochondria. Proc. Nat. Acad. Sci. U.S.A. 61:130-137.

18. Schönherr, O. Th., and H. M. Keir. 1972. The activity of deoxyribonucleic acid polymerase in some species of algae. Biochem. J. 129:285-290.

19. Schönherr, O. Th., and F. Warka. 1971. An investigation of DNA polymerase in synchronously growing Chlorella cells. Biochim. Biophys. Acta 232:83-93.

20. Sedwick, W. D., T. S.-F. Wang, and D. Korn. 1972. Purification and properties of nuclear and cytoplasmic deoxyribonucleic acid polymerases from human $\mathrm{KB}$ cells. J. Biol. Chem. 247:5026-5033.

21. Shapiro, A. L., E. Vinuela, and J. V. Maizel. 1967. Molecular weight estimation of polypeptide chains by electrophoresis in SDS-polyacrylamide gels. Biochem. Biophys. Res. Commun. 28:815-820.

22. Stout, E. R., and M. Q. Arens. 1970. DNA polymerase from maize seedlings. Biochim. Biophys. Acta 213:90-100

23. Tarr, H. L. A., and L. Gardner. 1971. Deoxyribonucleic acid polymerase from immature testes of salmon. Can. J. Biochem. 49:19-27.

24. Van Etten, J. L., R. K. Koski, and M. M. El-Olemy. 1969 Protein synthesis during fungal spore germination. IV. Transfer ribonucleic acid from germinated and ungerminated spores. J. Bacteriol. 100:1182-1186.

25. Weissbach, A., A. Schlabach, B. Fridlender, and A Bolden. 1971. DNA polymerases from human cells Nature N. Biol. 231:167-170.

26. Wintersberger, U., and E. Wintersberger. 1970. Studies on deoxyribonucleic acid polymerases from yeast. 1. Partial purification and properties of two DNA polymerases from mitochondria-free extracts. Eur. J. Biochem. 13:11-19.

27. Wintersberger, U., and E. Wintersberger. 1970. Studies on deoxyribonucleic acid polymerases from yeast. 2 . Partial purification and characterization of mitochondrial DNA polymerase from wild type and respiration deficient yeast cells. Eur. J. Biochem. 13:20-27. 